ISLAMIC BANKING: Jurnal Pemikiran dan Pengembangan Perbankan Syariah, Volume 7 Nomor 2 Edisi Februari 2022

\title{
CUSTOMER PREFERENCES FOR IB HASANAH CARD PRODUCTS AS FINANCIAL CARD AT BNI SYARIAH BANK SURABAYA BRANCH
}

\author{
Andro Agil Nur Rakhmad \\ Faculty of Economics, Universitas Negeri Malang \\ Email: andro.agil.fe@um.ac.id \\ Kurniawati Meylianingrum \\ Faculty of Economics, Universitas Islam Negeri Maulana Malik Ibrahim Malang \\ Email: meylianingrum@uin-malang.ac.id
}

\begin{abstract}
Currently, the Islamic finance industry is proliferating and continues to make exciting innovations to attract customers. This innovation offers convenience and efficiency in financing Islamic banking in Indonesia. one of the product innovations offered is a sharia credit card. Unlike conventional banks' credit cards, which based on interest, this Islamic credit card still based on a contract. This study aims to look at the preferences of sharia bank customers, especially at the Surabaya branch of BNI Syariah bank, in using the $i B$ hasanah card product. The method used in this study is a quantitative method with an explanatory approach. This study indicates that contracts, fines, fees, and services together have a positive effect on customer preferences in choosing the $i B$ Hasanah Card product. Furthermore, each variable significantly affects customer preferences in choosing the IB Hasanah Card as an efficient payment card.
\end{abstract}

Keyword: Sharia Card, Financial Card, Islamic Banking

\begin{abstract}
Abstrak
Saat ini, industri keuangan syariah sedang menjamur dan terus melakukan inovasiinovasi menarik untuk menggaet nasabah. Inovasi ini menawarkan kemudahan dan efisiensi dalam pembiayaan perbankan syariah di Indonesia. salah satu inovasi produk yang ditawarkan adalah kartu kredit syariah. Berbeda dengan kartu kredit bank konvensional yang berdasarkan bunga, kartu kredit syariah ini masih berdasarkan akad. Penelitian ini bertujuan untuk melihat preferensi nasabah bank syariah khususnya pada bank BNI Syariah cabang Surabaya dalam menggunakan produk iB hasanah card. Metode yang digunakan dalam penelitian ini adalah metode kuantitatif dengan pendekatan explanatory. Penelitian ini menunjukkan bahwa kontrak, denda, biaya, dan layanan secara bersama-sama berpengaruh positif terhadap preferensi nasabah dalam
\end{abstract}


memilih produk iB Hasanah Card. Selanjutnya masing-masing variabel berpengaruh secara signifikan terhadap preferensi nasabah dalam memilih IB Hasanah Card sebagai kartu pembayaran yang efisien.

Kata Kunci: Kartu Syariah, Kartu Kredit, Perbankan Syariah

\section{Introduction}

In the era of modern as today, especially in the economic field has been circulating system of financial transaction cards or more in the know with a credit card the first time appeared in America in 1920 and developed in European countries, and then began to evolve broadly in Islamic countries and non-Muslims (Ardha, 2020). This system, if implemented in economic and trade practices, has a high effectiveness and profit function. Indonesia issued credit cards in 1988, which PT Diners Jaya Indonesia manages (Ardha, 2020). After the issuance of the credit card, conventional banks examine the characteristics of the community and interest in credit cards so that they can attract all levels, especially the rich and middle class, to participate in this system. Marketing focused on the positives side of this card in its security, prestige and satisfaction of material desires and ambitions. Ads served to cover the negative aspects of the community, whether religious, social, or economic, such as debt and interest that the layman does not recognize.

Contrary to the concept of sharia economics, this credit card includes the fees charged in purchase transactions, fees for cash credits, fees for exchanging foreign currency, and interest on late payments to the swelling debt that the borrower must pay. All of them are in the form of debt that burdens the cardholder to not bear it in the future, especially people who have limited income. All of this happened because the agreement between the cardholder and the card issuer was not open. There were only vague and unclear signs as if there was no form of transaction calculations between them. In comparison, the agreement is used as a bond by the bank to get the maximum profit. The bank gets a higher profit compared to the interest income obtained from other applications and products.

The credit card business in Indonesia continues to grow every year. However, from 2020 to 2021, this has decreased due to the COVID- 19 pandemic. Bank Indonesia noted that in February 2021, the number of credit cards in circulation or held by the 
ISLAMIC BANKING: Jurnal Pemikiran dan Pengembangan Perbankan Syariah, Volume 7 Nomor 2 Edisi Februari 2022

public was 16.8 million cards. This number decreased by 0.85 per cent compared to the previous year. The number of credit cards in circulation ever reached the highest in 2019, namely 17.5 million cards (Bank Indonesia, 2021). Even now, there are types of credit cards in circulation that use the sharia system.

Table 1. Number of Credit Cards in circulation

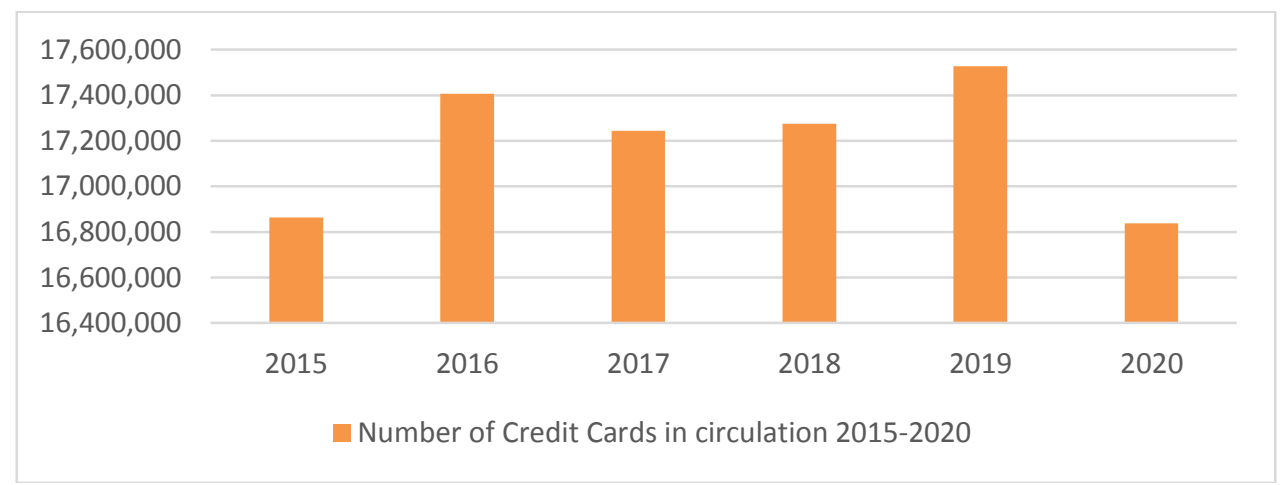

Source: Bank Indonesia, 2021

Coinciding with the Sharia Economic Festival (FES) organized by Bank Indonesia, the Sharia Business Unit of PT. Bank Negara Indonesia (Persero), Tbk (BNI Syariah) has launched one type of credit card-based financing, namely the Hasanah Card, in collaboration with the MasterCard International provider. "The launch of this product is one of our commitments to provide banking products and services under the needs of the community with a modern lifestyle based on sharia principles," said BNI President Director Gatot M. Suwondo at the Hasanah Card launch event on the sidelines of the Sharia Economics Festival (FES) 2009 in Jakarta. The basis used in the issuance of the Hasanah Card is the Fatwa of the National Sharia Council (DSN) No.54/DSNMUI/X/2006 regarding the Sharia Card and the Letter of Approval from Bank Indonesia No.10/337/DPbs dated 11-03-2008.

According to the DSN Fatwa No.54/DSN-MUI/X/2006 concerning Sharia Card, it defined as a card that functions as a credit card whose legal relationship between the parties is based on sharia principles as stipulated in the said fatwa. The IB hasanah card is a financing card that functions as a credit card based on sharia principles, namely with a fixed, fair, transparent and competitive fee calculation system without interest calculation. With the Mastercard network, the IB Hasanah Card offers convenience and 
the right financial solution for customers because this card can be used all over the world.

There are quite a several Sharia Card users at BNI Syariah spread throughout Indonesia. As of the first semester of 2018, 270,000 pieces of iB Hasanah Card credit cards have been circulated to the public (Ihdi, 2020). The achievement of these transactions recorded an increase of $14.59 \%$ compared to the same period in the previous year. Likewise, the development of the use of Syariah Cards at BNI Syariah in 2019 continued to increase. The Corporate Secretary of BNI Syariah Rima Dwi Permatasari that as of September 2019, the number of iB Hasanah Card users was 304,494 customers (Ihdi, 2020). Rima Dwi Permatasari also said the number of users iB Hasanah Card up to 2020 accounting for about 350,000 customers. This number increased compared to the position in September 2019 of 304,494 customers (Ihdi, 2020). In line with the increase in the number of users, the number of iB Hasanah Card transactions has also increased to reach IDR 1.2 trillion (Ihdi, 2020).

BNI Syariah has collaborated for payments using the IB Hasanah Card with merchants of more than 60 hotels and restaurants spread across major cities in Indonesia. In Indonesia, BNI IB Hasanah Card has penetrated the international market by collaborating with more than 20 halal restaurants and hotels in Japan in Tokyo, Osaka, Hokkaido, and Takushima.

The behaviour and paradigm applied in the daily life of a Muslim must have a priority scale. Therefore, Islamic credit card usage is not on the priority dharuriyat (primary), while another financing is more readily accepted the credit card is not required. So, credit cards are a priority category for hajiyat (secondary) and even priority tahsiniyyat/kamaliyyat (complementary) if there are other types of financing, such as debit cards. Therefore, a credit card is allowed if there is no debit card or cash payment facility and it is not a basic need.

With the enthusiasm of the community using the IB Hasanah Card as payment, it necessary to conduct a study on the customers of the IB Hasanah Card Bank BNI Syariah Surabaya Branch to analyze customer preferences or interests in the IB Hasanah Card (Sharia Card) by looking at the factors that influence customer preferences, 
ISLAMIC BANKING: Jurnal Pemikiran dan Pengembangan Perbankan Syariah, Volume 7 Nomor 2 Edisi Februari 2022

namely contract variables, fees, fines and services on the IB Hasanah Card product. As a financial card at Bank BNI Syariah Surabaya Branch.

\section{Methodology}

This study uses a quantitative method with an explanatory approach to see the preferences and interests of the community towards the IB Hasanah Card (Sharia Card) product at Bank BNI Syariah Surabaya Branch. This study uses an attitude scale, and this scale only used to measure attitudes. The development of sociology and psychology uses this to measure attitudes precisely. Several attitude scales can be used for administrative, educational and social research. With the Likert scale, this research used to measure people's attitudes, opinions, and perceptions about social phenomena or phenomena that occur.

This research took place at BNI Syariah Surabaya Branch. The sampling technique in this study uses non-probability sampling, which means that each member of the population does not have the same opportunity or opportunity as the sample. A minimum sample determination technique is considered representative to determine the number of respondents sampled in this study. The sampling used in this research is by using the Purposive Sampling method.

\section{Discussion and Results}

\section{a. Validity and Reliability Test}

Validity is carried out on the question items on the questionnaire by calculating the correlation coefficient of each question with the total score obtained and then compared with the critical number $r$ product moment. To assist in the calculation of the instrument test, the validity of this using the application programme SPSS version 20, following the results of Uji validity, appear in Table 4.1 
Table 4.1 Validity Test Results

\begin{tabular}{|c|c|c|c|c|}
\hline Variable & Indicator & $\begin{array}{c}\text { Total } \\
\text { Pearson } \\
\text { Correlation }\end{array}$ & $\begin{array}{c}\mathrm{r} \\
\text { Critical }\end{array}$ & Note: \\
\hline (X1) & $\mathrm{X}_{1-1}$ & 0364 & 0312 & Valid \\
& $\mathrm{X}_{1-2}$ & 0701 & 0312 & Valid \\
& $\mathrm{X}_{1-3}$ & 0.683 & 0312 & Valid \\
& $\mathrm{X}_{1-4}$ & 0.602 & 0312 & Valid \\
\hline (X 2 ) & $\mathrm{X}_{2-1}$ & 0364 & 0312 & Valid \\
& $\mathrm{X}_{2-2}$ & 0701 & 0312 & Valid \\
& $\mathrm{X}_{2-3}$ & 0.683 & 0312 & Valid \\
& $\mathrm{X}_{2-4}$ & 0.602 & 0312 & Valid \\
\hline (X 3 ) & $\mathrm{X}_{3-1}$ & 0364 & 0312 & Valid \\
& $\mathrm{X}_{3-2}$ & 0701 & 0312 & Valid \\
& $\mathrm{X}_{3-3}$ & 0.683 & 0312 & Valid \\
& $\mathrm{X}_{3-4}$ & 0.602 & 0312 & Valid \\
\hline (X 4 ) & $\mathrm{X}_{4-1}$ & 0364 & 0312 & Valid \\
& $\mathrm{X}_{4-2}$ & 0701 & 0312 & Valid \\
& $\mathrm{X}_{4-3}$ & 0.683 & 0312 & Valid \\
& $\mathrm{X}_{4-4}$ & 0.602 & 0312 & Valid \\
\hline ( Y ) & $\mathrm{Y}_{-1}$ & 0364 & 0312 & Valid \\
& $\mathrm{Y}_{-2}$ & 0701 & 0312 & Valid \\
& $\mathrm{Y}_{-3}$ & 0.683 & 0312 & Valid \\
& $\mathrm{Y}_{-4}$ & 0.602 & 0312 & Valid \\
\hline
\end{tabular}

Source: Data processed

Based on table 4.1 above, it can be seen that all questions that measure the variables of Contracts, Fees, Fines and Services are said to be valid because the total Pearson correlation > critical r-value of 0.312 .

In this study, the alpha coefficient or Cronbach's alpha used to measure internal consistency. A measuring instrument considered reliable if the Cronbach alpha value > 0.60 , then the item or question item is reliable. In testing the reliability of this research instrument, the researcher uses the SPSS application. The results of the reliability test shown in Table 4.2 
ISLAMIC BANKING: Jurnal Pemikiran dan Pengembangan Perbankan Syariah, Volume 7 Nomor 2 Edisi Februari 2022

Table 4.2 Reliability Test Results

\begin{tabular}{|c|c|}
\hline Cronbach's Alpha & N of Items \\
\hline 0.915 & 21 \\
\hline
\end{tabular}

From table 4.2, it could be seen that all variables, namely contracts, fees, fines and services reliable because the Cronbach alpha value is more significant than 0.6.

\section{b. Regression Test}

To determine the formulation of a simple regression equation between the effect of Contracts, Fees, Fines and Services on customer decisions in choosing the IB Hasanah Card product as a Financial Card at Bank BNI Syariah Surabaya Branch, regression coefficient analysis was performed. $M$ enggunakan sig level nifikansi of $5 \%$ was obtained results as follows:

Table 4.3 Regression Test Results

Coefficients ${ }^{\text {a }}$

\begin{tabular}{|c|c|c|c|c|c|c|c|c|}
\hline \multirow{2}{*}{\multicolumn{2}{|c|}{ Model }} & \multicolumn{2}{|c|}{$\begin{array}{c}\text { Unstandardized } \\
\text { Coefficients }\end{array}$} & \multirow{2}{*}{$\begin{array}{c}\begin{array}{c}\text { Standardized } \\
\text { Coefficients }\end{array} \\
\text { Beta }\end{array}$} & \multirow[t]{2}{*}{$\mathrm{t}$} & \multirow[t]{2}{*}{ Sig. } & \multicolumn{2}{|c|}{$\begin{array}{c}\text { Collinearity } \\
\text { Statistics }\end{array}$} \\
\hline & & B & Std. Error & & & & Tolerance & VIF \\
\hline \multirow{5}{*}{1} & (Constant) & , 148 & 1,915 & & 0.077 & ,939 & & \\
\hline & $\mathrm{X} 1$ & ,366 &, 180 & ,285 & 2.029 & 0.050 & ,318 & 3,146 \\
\hline & $\mathrm{X} 2$ & , 136 &, 156 &, 124 & ,869 & .031 &, 306 & 3,265 \\
\hline & X3 & ,208 &, 170 & ,196 & 1.218 & ,02 1 & ,242 & 4,135 \\
\hline & $\mathrm{X} 4$ & ,512 & , 137 & ,407 & 3,735 & .001 & ,529 & 1,889 \\
\hline
\end{tabular}

a. Dependent Variable: Y

The following equation is obtained:

$$
\mathrm{Y}=0,148+\beta_{1} 0,366+\beta_{2} 0,136+\beta_{3} 0,208+\beta_{4} 0,512
$$

Based on the regression equation above, it can be seen the magnitude of the coefficient and the direction of influence of each independent variable. The explanation of the effect of each independent variable on the dependent variable is as follows:

a. The constant value is 0.148 , meaning that the customer's decision in choosing the IB Hasanah Card product as a Financial Card at the Surabaya Branch of BNI Syariah Bank is 0.148 units, with this assumption that the Contract, Fees, Fines and Services are in a constant/fixed state. 
b. $\quad b_{1}($ Regression coefficient direction of influence (contract) and $Y)=0.366$, this value has a positive sign which means the contract contained in product IB Hasanah Card (Shariah Card), the customer would interest in choosing a product IB Hasanah Card will increasingly influential on customer decisions in it. If the value of the contract regression coefficient increases by 0.366 , influence of customer decisions increase 0.366 . Otherwise, if the regression coefficient of the contract variable decreases by 1 unit score, the contract variable decreases by 0.366 .

c. $\quad b_{2}$ (Regression coefficient direction of influence (fines) and $\mathrm{Y}$ ) $=0.136$, this value has a positive sign which means fines on the IB Hasanah Card (Shariah Card) product got lower would influence on customer decisions in choosing IB Hasanah Card products at Bank BNI Syariah Surabaya Branch. If the value of the regression coefficient for fines increases by 0.136 , the increase in interest in customer decisions increases by 0.136 . Otherwise, if the regression coefficient of the penalty decreases by 1 unit score, the penalty decreases by 0.136 .

d. $\quad b_{3}$ (Regression coefficient of direction of influence (cost) and $Y$ ) $=0.208$, this value has a positive sign which means that the cost of the IB Hasanah Card (Shariah Card) product got lower, customers more interested to choosing the IB Hasanah Card product and would influence on customer decisions in choosing IB Hasanah Card products at Bank BNI Syariah Surabaya Branch. If the value of the incentive regression coefficient increases by 0.208 , the increase in customer decision interest increases by 0.208 . Otherwise if the cost regression coefficient decreases by 1 unit score, the cost decreases by 0.208 .

e. $\mathrm{b}_{4}$ (Regression coefficient of direction of influence (Service) and $\mathrm{Y}$ ) $=0.512$, this value has a positive sign which means that services provided by Bank BNI Syariah employees on the IB Hasanah Card (Syariah Card) product, the customer's interest in choosing IB products Hasanah Card will increasingly influence customer decisions in choosing IB Hasanah Card products at Bank BNI Syariah Surabaya Branch. If the value of the incentive regression coefficient increases by 0.512 , then the service increases by 0.512 . Otherwise if 
ISLAMIC BANKING: Jurnal Pemikiran dan Pengembangan Perbankan Syariah, Volume 7 Nomor 2 Edisi Februari 2022

the regression coefficient of the service decreases by 1 unit score, the service decreases by 0.512 .

\section{c. Coefficient of Determination Test}

To determine the results of the Coefficient of Determination Test, the researchers used SPSS aplication as shown in Table 4.4.

Table 4.4 Model Summary

\begin{tabular}{|l|r|r|r|r|}
\hline Model & $\mathrm{R}$ & $\mathrm{R}$ Square & $\begin{array}{c}\text { Adjusted R } \\
\text { Square }\end{array}$ & $\begin{array}{r}\text { Std. Error of } \\
\text { the Estimate }\end{array}$ \\
\hline 1 &, $883^{\mathrm{a}}$ &, 780 &, 755 & 1.01447 \\
\hline
\end{tabular}

a. Predictors: (Constant), X4, X3, X1, X2

Based on the calculation table 4.4 adjusted $\mathrm{R}^{2}$ of 0755 . Value $\mathrm{R}^{2}$ relatively large shows that Akad, Fines, Fees and services have a relationship that is very strong, or it can be said that the interest of the customer's decision has had enormous influence on the Akad, Fines, Fees and Services.

\section{d. Hypothesis Test}

To examine whether the hypothesis is accepted or rejected, a significant test is carried out by consulting the t-count value with the t-table value at a $95 \%$ confidence level $(\alpha=0.05)$ so that a $5 \%$ significance level is used for the theoretical hypothesis to be used as a working hypothesis. The results of the t-test are shown in Table 4.5 .

Table 4.5 T Uji test

Coefficients $^{\text {a }}$

\begin{tabular}{|c|c|c|c|c|c|c|}
\hline \multirow{2}{*}{\multicolumn{2}{|c|}{ Model }} & \multicolumn{2}{|c|}{ Unstandardized Coefficients } & \multirow{2}{*}{$\begin{array}{l}\text { Standardized } \\
\text { Coefficients } \\
\text { Beta }\end{array}$} & \multirow[t]{2}{*}{$\mathrm{t}$} & \multirow[t]{2}{*}{ Sig. } \\
\hline & & $\mathrm{B}$ & Std. Error & & & \\
\hline \multirow{5}{*}{1} & (Constant) &, 148 & 1,915 & & 0.077 & ,939 \\
\hline & $\mathrm{X} 1$ & ,366 & , 180 & ,285 & 2.029 & 0.050 \\
\hline & $\mathrm{X} 2$ &, 136 & , 156 &, 124 & ,869 & .031 \\
\hline & $\mathrm{X} 3$ & ,208 & 170 & , 196 & 1.218 & 021 \\
\hline & $\mathrm{X} 4$ &, 512 & 137 & ,407 & 3,735 & .001 \\
\hline
\end{tabular}

a. Dependent Variable: Y 


\section{Influence of Contracts on Customer Decisions}

Based on variable of contract regression result coefficient postively equal to 0.366 and the statistical $t$ test that generates a probability value or significance of 0.05 or equal to $\alpha(0.05)$, the obtained whispering mpulan that Akad influential positive significantly to Customer Decision . Based on this, the H1 is accepted.

The reason underlying the contract has a positive effect on customer decisions is that the existing contract on the IB Hasanah Card product follows Fiqh/Islamic Law and the fatwa from DSN-MUI NO: 54/DSN-MUI/X/2006 regarding Sharia Card. According to the term, sometimes the word contract is used in a general sense, something bound by someone for himself or others with the word must. Buying and selling and the like are contracts. Everything required of a person on himself in the form of nadzar, paths, and a contract.

\section{Effect of Fines on Customer Decisions}

Based on the results of the positive Cost variable regression coefficient, which is 0.136 and the result of the $t$ statistic test, which produces a probability or significance value of 0.031 or less than (0.05), it concluded that fines have a significant positive effect on Customer Decisions. Based on this, then $\mathrm{H} 2$ is accepted.

The underlying reason, fines positively the customer decision due to penalties on products IB Hasanah Card not burdensome, lower / even none of the products Syariah Card on the institution of Islamic banking more, meaning that the risk borne by the Customer IB Hasanah Card in payment of fines no, because BNI Syariah also gives appreciation to its customers in the form of the Cash Rebate feature, namely the exemption of fines for customers who pay bills on time. With the features of BNI Syariah, this factor becomes an interest in customer decision making on the IB Hasanah Card product.

\section{The Effect of Costs on Customer Decisions}

Based on the results of a positive cost variable regression coefficient of 0.208 and the results of the $t$ statistic test, which produces a probability or significance value of 0.021 or less than (0.05), it concluded that the cost has a significant positive effect on the decision. Customer. B erdasarkan this, the $\mathrm{H} 3$ is received. 
ISLAMIC BANKING: Jurnal Pemikiran dan Pengembangan Perbankan Syariah, Volume 7 Nomor 2 Edisi Februari 2022

The reason underlying the fee has a positive effect on Customer Decisions is because the costs in the IB Hasanah Card product are following the provisions of the sharia banking rules in the DSN-MUI. Namely, wages or fees received by the bank in return for issuing $\mathrm{L} / \mathrm{C}$ are permissible.

The Hasanah card has set a maximum fee based on the approved card limit called the Monthly Fee. The aim is to calculate the actual equivalent fee charged to hasanah cardholders, which is called the Net Monthly Fee, where all card limits start from the smallest $\operatorname{Rp} 4$ million to the most extensive $\mathrm{Rp} 900$ million compared to the monthly fee for each card limit, have the exact equivalent of $2.95 \%$. In addition to the fatwa from the DSN-MUI, the most important thing is that the IB Hasanah Card product costs do not burden its customers, and these costs explained transparently when the customer registers for the IB Hasanah Card product.

\section{The Effect of Service on Customer Interest}

Based on the positive service variable regression coefficient of 0.512 and the results of the $t$ statistic test, which produces a probability or significance value of 0.001 or less than (0.05), it concluded that the service has a significant positive effect on customer decisions. Based on this, then H4 is accepted.

The underlying reason for performance positively affects the Customer Decision is that service quality caused by service ( service ) does not merely deliver or serve. Service means understanding, understanding, and feeling so that the delivery will be about the consumer's heart share and ultimately strengthen the position in the consumer's mind share. With the embedded heart share and mind share, a consumer's loyalty to the company's product or business will not be doubted.

\section{Conclusion}

The IB Hasanah Card ( Syariah Card ) establishes an Akad different from conventional Credit Cards in general, which apply an exciting system. The IB Hasanah Card is well known to the broader community. It was proven when researchers gave interviews and questionnaires given to respondents about the IB Hasanah Card that 
almost all IB Hasanah Card customers already knew and understood about the IB Hasanah Card before becoming an IB Hasanah Card customer.

Characteristics of customers in terms of demographics, economics, and social are very diverse. From the demographic (religious) side, it proves that the IB Hasanah Card is a product that is relied on by the Muslim community and non-Muslim communities. The educational background is also very diverse, starting from high school to the Masters (S2) level. When viewed from different characteristics and covers all elements of society, this will have an incredible impact on the development of the IB Hasanah Card and from interviews conducted by researchers, they will use this product in the future.

Customer preferences regarding the IB Hasanah Card are very diverse. No previous research examines customer preferences or interests in making decisions for the IB Hasanah Card. From the researchers using the applied variables, many things ranging from Contracts, Fees, Fines, and Services are factors that customers choose the IB Hasanah Card. More interested in Contracts that provide convenience in transactions, very cheap fees, fines that are abolished by BNI Syariah as a form of customer appreciation in timely repayment and good service from BNI Syariah to IB Hasanah Card customers are important factors that cause prospective customers to become customers IB Hasanah Card eventually. 
ISLAMIC BANKING: Jurnal Pemikiran dan Pengembangan Perbankan Syariah, Volume 7 Nomor 2 Edisi Februari 2022

\section{BIBLIOGRAPHY}

Ardha, D. J. (2020). Analisis Kasus Pemalsuan Kartu Kredit Sebagai Bentuk Tindak Pidana Perbankan. Jurnal Hukum Doctrinal, 5(2), 245-263.

Chrysanthini, B., Sumarwan, U., \& Rifin, A. (2018). Preferensi Konsumen terhadap Produk Sayuran Organik (Studi Kasus Konsumen UD Fabela-Myfarm) di Bogor Jawa Barat. MANAJEMEN IKM: Jurnal Manajemen Pengembangan Industri Kecil Menengah, 12(2), 151. https://doi.org/10.29244/mikm.12.2.151-160

Dewi, A. S., \& Satria, A. D. (2017). Perceived of Religious Value: Model Pembentuk Preferensi Nasabah Bank Syariah. Jurnal Bisnis Dan Manajemen, 14(2), 35. https://doi.org/10.20961/jbm.v14i2.4124

Farkhiyah, I., \& Sukamto, S. (2020). Tinjauan Maqashid Al-Syariah dalam Produk iB Hasanah Card Pperbankan Syariah. Mu'allim Jurnal Pendidikan Islam, 2(1), 1-14.

Ihdi, A. (2020). Analisis Perilaku Konsumen Syariah Card. Yurisprudentia: Jurnal Hukum Ekonomi , 6, 248-268., 6(2).

Norman, E. (2020). Syari'ah Card (Kartu Kredit Syariah) Ditinjau dari Maqashid Syari'ah dan Asas Manfaat. Al-Kharaj: Jurnal Ekonomi, Keuangan \& Bisnis Syariah, 2(2), 182-195. https://doi.org/10.47467/alkharaj.v2i2.113

Russetyowati, A. (2018). Peningkatan Minat Penggunaan Kartu Kredit Syariah Melalui Pendekatan Kepercayaan, Sikap, dan Pendapatan. Journal of Finance and Islamic Banking, 1(1), 39-54. https://doi.org/10.22515/jfib.v1i1.728

Tumbelaka, A., Kindangen, P., \& Kalangi, J. A. F. (2019). Preferensi Konsumen Dalam Memilih Bank BRI dan Bank BCA Di Manado Berdasarkan Kualitas Pelayanan. $\begin{array}{llll}\text { Jurnal Administrasi } & \text { Bisnis, } & 9(1), & 10 .\end{array}$ https://doi.org/10.35797/jab.9.1.2019.23518.10-18

Wardani, F. A. (2016). Kartu Kredit Syariah dalam Tinjauan Islam. Jurnal Ekonomi Syariah, 1(2), 33-44. 
296 Andro Agil Nur Rakhmad \& Kurniawati Meylianingrum, CUSTOMER PREFERENCES FOR IB HASANAH.......... 